\title{
A STUDY OF ADOLESCENTS' ANXIETY AND ACHIEVEMENT IN ENGLISH AS A FOREIGN LANGUAGE
}

\author{
Ridha Fadillah
}

Email: ridhappb@yahoo.co.id
Institut Agama Islam Negeri (IAIN) Antasari Banjarmasin

Alamat Korespondensi: “Dian Salon” Komp. Cahaya Ratu Elok. Jalan Tauman No. 5. Kel. Sei Besar.

Barjarbaru Selatan. Kalimantan Selatan. Kode Pos 70714

\begin{abstract}
This paper aims at investigating whether there is relationship between students' anxiety and students' achievement in English as a foreign language among adolescents at Sekolah Menengah Umum Negeri 1 Banjarbaru, South Kalimantan. The sample was 152 students of sixteen and seventeen years old at second grade. The results indicate that the students' anxiety in learning English as foreign language is at moderate level. There is no significant relationship between English language anxiety and students' achievement in English as a foreign language as a whole. But a significant negative correlation between test anxiety and students' achievement is indicated. And the difference of English language anxiety between male and female occurred on communication apprehension, it shows that female is more apprehensive than male in English communication but for overall anxiety, there is no difference in English language anxiety by gender at second grade in this school.
\end{abstract}

\section{Keywords}

Foreign Language Anxiety, Achievement, Adolescents, Gender

\section{Introduction}

In learning a language as second language or foreign language, in this case is English, non native speaker students have difficulties to master that particular language. One factor that influences the success and failure in learning and teaching a foreign language is anxiety. Anxiety plays an important role in foreign language students' classroom performance. Elkhafaifi (2005), quoting Horwitz, Horwitz, \& Cope (1986), determined that anxiety plays an important role in determining students' success or failure in foreign language classes. They pointed out that students' anxiety will influence negatively students' achievement in language learning.

Anxiety is a problem for many foreign language students. There are many studies connected with anxiety and students' achievements that have been conducted by many educators, language teachers, experts in education and researchers. They have been interested in the phenomenon of foreign language anxiety for a number of years. From previous studies (Horwitz, Horwitz, \& Cope, 1986; Price, 1988; Aida, 1994; Cassado \& Dereshiwsky, 2001; Gregersen \& Horwitz, 2002; Daley, 2003; Wörde, 2003; Elkhafaifi, 2005;
Woodrow, 2006; Na, 2007) conducted in Western and Non-Western languages and countries, the results showed that foreign language anxiety was negatively correlated to achievement (final grade, listening and speaking performance, and production of vocabulary) and there was no difference significant anxiety between male and female that effect on achievement (Price, 1988; Aida, 1994; Woodrow, 2006; Na, 2007). That is, students with high anxiety will gain low achievement; on the contrary, students with low anxiety will gain high achievement. However, the researcher feels that this finding may not apply to the situation in Indonesia. So the researcher wanted to find out whether in Indonesia, the relationship between anxiety and students' achievement in English as a foreign language would be similar or different from studies done in Western countries.

Horwitz (2001:113) defined that "anxiety is the subjective feeling of tension, apprehension, nervousness, and worry associated with an arousal of the autonomic nervous system". The statement shows that anxiety is an unpleasant feeling felt by someone; a fear of something that happens in the nervous system. After examining the role of related types of anxiety in language 
learning-specifically

communication apprehension, fear of negative evaluation, and test anxiety - Horwitz, Horwitz, \& Cope (1986) cited in Horwitz \& Young (1991) concluded that language anxiety is a type of anxiety unique to second-language learning.

Elkhafaifi (2005:207) quoting Horwitz, Horwitz, \& Cope (1986) defined foreign language anxiety is "a distinct complex of self-perceptions, beliefs, feelings, and behaviors related to classroom language learning arising from the uniqueness of the language learning process, it may arise from self-doubt, frustration, and perceived (or fear of ) failure". Therefore, most teachers are familiar with test anxiety and public-speaking anxiety that happen to the students during language learning process in the classroom. To reduce the students' language learning anxiety, it will require the cooperative efforts of both teacher and students. Teacher must help students understand why the students become anxious and offer them strategies for coping with anxiety.

Horwitz \& Young (1991) stated that language anxiety contributes to an affective filter which makes the student unreceptive to language input; thus, the student fails to comprehend the target language messages and language acquisition does not develop. The anxious student also feels shy when attempting to use the second language. The unsuccessful result on test performance and inability to perform in language classroom can cause a teacher to be inaccurate in assessing the student; the teacher may think that the student has low aptitude for learning a language or low motivation to do the work needed for a good performance.

Horwitz, Horwitz, \& Cope (1986) wrote that listening and speaking were main sources of anxiety. Lack of preparation and free speech can make students feeling anxious. Sound and linguistic structure discrimination make it difficult for students to understand the messages. And problems observed by Horwitz et al. include difficulty in recalling the lessons under anxious conditions (such as examinations), overstudying as a reaction, avoiding the situation as in learned helplessness, and a fear of making mistakes that makes students keep silent and not participate. All of these reactions are consistent with the general literature on anxiety and describe some behaviors of anxious students in language learning context.

Since the middle of 1960s scholars have entertained the possibility that anxiety interferes with second language learning and performance. They were Aida (1994) had conducted a study on
96 students (56 males and 40 females) who were enrolled in 2nd year at the University of Texas at Austin. There was a moderate negative correlation between anxiety and course grade, indicating that the higher the students' level of anxiety, the more likely they were to receive low grades. Casado \& Dereshiwsky (2001) conducted a study to investigate 114 students (Group One) and 169 students (Group Two) at Northern Arizona University. They found that some levels of foreign language anxiety; communication apprehension, fear of negative evaluation, and general feeling of anxiety; were experienced by beginning students. Daley (2003) conducted a study on 259 students at a US mid-southern university. The result was revealed that students who dropped out of their foreign language classes tended to report statistically significantly higher levels of anxiety experienced at the input, processing, and output stages. Elkhafaifi (2005) conducted a study on 233 students from 6 United States universities enrolled in Arabic language programs. The results of this study revealed significant negative correlations among listening and Foreign Language learning anxiety, students' listening comprehension scores, and final grades as a measure of overall achievement. The relationship of both listening anxiety and learning anxiety to achievement, as indexed by listening scores and final course grades was negative. And the results also found significant negative correlations between Foreign Language anxiety (FLCAS) and the final listening comprehension grades, and showed significant negative correlations between Foreign Language anxiety and the final general grades as a measure of overall achievement. Gregersen \& Horwitz (2002) conducted a study to examine the connection between foreign language-anxious and perfectionist students on 8 students (4 most anxious and 4 least anxious according to their scores on the FLCAS at the Universidad de Atacama in Chile. They found that anxious and non-anxious foreign language learners do differ in terms of their self-reports of perfectionist tendencies. Anxious learners reported higher standards for their performance, a greater tendency toward procrastination, greater worry over the opinions of other, and a higher level of concern over their errors than the non-anxious learners. In 1986, Horwitz, Horwitz, \& Cope offered an instrument, the Foreign Language Classroom Anxiety Scale (FLCAS). They conducted a study on 225 students at the University of Texas, they found that significant foreign language anxiety is experienced by many students in response to at least some aspects of foreign language learning (Horwitz, 1986). Horwitz, Horwitz, \& Cope (1986) pointed out that 
studies using the FLCAS and other specific measures of second language anxiety have found a consistent moderate negative correlation between FLCAS and measures of second language achievement (typically final grade). Their findings have been supported by more recent studies (Price, 1988; Aida, 1994; Cassado \& Dereshiwsky, 2001; Gregersen \& Horwitz, 2002; Daley, 2003; Wörde, 2003; Elkhafaifi, 2005; Woodrow, 2006; Na, 2007).

$\mathrm{Na}$ (2007) surveyed and analyzed 115 students (56 males and 59 females) from a high school in Shandong Province, China. The results of the relationship analysis indicated that anxiety and English achievement were only correlated in terms of test anxiety, and they were negatively correlated. It was found that anxiety of English classes indeed significantly affected high school students' English achievement.

A research was done by Price (1988) on 106 students enrolled in second semester French classes at University of Texas at Austin; 44 males and 62 females. No significant relationship was found between foreign language anxiety and age, sex, or year in school.

And the other findings are there was a significant negative correlation between foreign language anxiety and final grade, indicating that high foreign language anxiety was associated with low final grades. Woodrow (2006) conducted a research on 275 (male $=139$ and female $=136$ ) students in several Australian universities. She found significant relationship between second language speaking anxiety and oral performance.

Wörde (2003) conducted a study of 15 students from a diverse set of language classroom (French, German, and Spanish). She found a significant negative correlation between the final foreign language grades and Foreign Language Classroom Anxiety Scale score.

From previous studies (Horwitz, Horwitz, \& Cope, 1986; Price, 1988; Aida, 1994; Cassado \& Dereshiwsky, 2001; Gregersen \& Horwitz, 2002; Daley, 2003; Wörde, 2003; Elkhafaifi, 2005; Woodrow, 2006; Na, 2007), the results showed that Foreign Language Anxiety was negatively correlated to Achievement (final grade, listening and speaking performance, and production of vocabulary) and there was no difference significant anxiety between male and female that effect on achievement (Price, 1988; Aida, 1994; Woodrow, 2006; Na, 2007). Aida (1994) in her study revealed that there was no significant gender differences found in language anxiety, and there was no significant anxiety-gender interaction effect on course grade. In both male and female groups, highly anxious students were more possible to receive lower grades than students having a low level of anxiety. Na (2007) examined the comparison of male and female students' language anxiety. And the results showed that there were no significant differences between males and females in most anxiety variables. Price (1988) investigated gender differences in language anxiety. She obtained that there were no differences in foreign language anxiety between males and females. Woodrow (2006) found that there was no significant difference in foreign language anxiety between males and females.

\section{Methodology \\ Population and Sample}

The population was all students at Sekolah Menengah Umum Negeri 1 Banjarbaru. There were 548 students, 328 female students and 220 male students. Grade one was 106 female students and 73 male students. Grade two was 121 female students and 67 male students. Grade three was 101 female students and 80 male students.

The sample was 188 students at Second (2nd grade Sekolah Menengah Umum Negeri 1 Banjarbaru, consisting of 121 female and 67 male students. The students' ages were about sixteen and seventeen years old. 36 students had been involved in pilot study, so 152 students were the respondents for the main study.

\section{Instrumentation}

In this study, the researcher used a questionnaire as the instrument. The questionnaire was divided into two parts; the background of the students in Part A included class/department, age, gender, parent's occupation, and informal education, and the foreign language classroom anxiety scale in Part B.

The independent variable, the students' anxiety was measured by the Foreign Language Classroom Anxiety Scale (FLCAS). FLCAS tested on three dimensions which are the students' communication apprehension, fear of negative evaluation, and test anxiety. It was a five-point Likert scale questionnaire, ranging from strongly agree (sangat setuju) to strongly disagree (sangat tidak setuju). The scale used range from one (1) for low to five (5) for high. Strongly agree (sangat setuju) was coded by 5 and strongly disagree (sangat tidak setuju) was coded by 1 and vice versa in coding negative statements. 
The questionnaire survey consisted of 33 questions. The items dealt with positive and negative sentences. Fifteen items were to measure students' communication apprehension; the item numbers were $1,4,9,11,13,14,15,18$, $23,24,27,29,30,31$, and 32 . Nine items were to measure students' fear of negative evaluation; they were items number $2,3,5,6,7,17,19,20$, 26. And nine items were to measure students' test anxiety; the numbers were $8,10,12,16,21$, $22,25,28$, and 33 .

(Horwitz, Horwitz \& Cope, 1986) Foreign Language Classroom Anxiety Scale (FLCAS) was adapted and translated into Indonesian adolescents' context.

The dependent variable, English achievement, was taken from students' mid semester examination scores.

\section{Data Collection}

To collect data on the students' foreign language anxiety, Horwitz, Horwitz, \& Cope's FLCAS was used while to collect data of students' achievement, the researcher obtained the students' English mid semester examination scores.

The 152 students submitted the completed questionnaire. The duration of main study was about 45 minutes. The researcher requested the students' English exam score from the English teachers (students' achievement in English).

\section{Data Analysis}

The English language anxiety data was analyzed by:

Determining the categories of English anxiety level and English achievement level, determining the Mean score for English anxiety, consisting of overall items, communication apprehension items, fear of negative evaluation items and test anxiety items. The Mean score for students' English achievement was also determined, determining the correlation between anxiety and students' achievement in English as a foreign language, determining the difference in English language anxiety between male and female students. And data was analyzed using the SPSS 12.

\section{Results and Discussion}

The level of foreign language anxiety of students' foreign language
Table 1 summarizes the descriptive statistics of the dimensions used in the research. It indicates that all the values for dimensions measured in Likert Scale are around their midpoint with a standard deviation below 1. As for dimensions measured using 5 point Likert scale, communication apprehension $(\mu=3.09$ and s.d $=$ 0.65 ) was recorded as the highest rating, followed by test anxiety ( $\mu=2.85$ and s.d $=0.69$ ). Fear of negative evaluation was recorded as the lowest mean rating $(\mu=2.73$ and s.d $=0.61)$. And overall anxiety showed $\mu=2.93$ and s.d $=0.60$. From the data, it can be concluded that level of students' anxiety was moderate level anxiety.

Table 1

Foreign language anxiety: Mean ratings and standard deviations

\begin{tabular}{lccc}
\hline & Mean & $\begin{array}{c}\text { Std. } \\
\text { Deviation }\end{array}$ & N \\
\hline Overall Anxiety & 2.93 & .60 & 152 \\
$\begin{array}{l}\text { Communication } \\
\text { Apprehension }\end{array}$ & 3.09 & .65 & 152 \\
$\begin{array}{l}\text { Fear of Negative } \\
\text { Evaluation }\end{array}$ & 2.73 & .61 & 152 \\
Test Anxiety & 2.85 & .69 & 152 \\
\hline
\end{tabular}

Within the three sub dimensions of language anxiety, students were comparatively most anxious about communicating, followed by taking test. They were least worried about negative evaluation.

The reasons for the results can be explored in two factors; internal factor and external factors. The internal factor is closely related with the students themselves: they probably did not feel very anxious in English as a foreign language classroom because they felt that they were in the same level both in English level and age. Wachidah (2004) suggested that studying with peers would not make students feel ashamed and clumsy to speak English because they only faced their friends. So it influenced their self confidence positively. The more confident a learner feels, the less anxiety he experiences in learning (Meng \& Wang, 2006).

Good relationship with classmates is assumed as one factor that can reduce the anxiety. Classmates' favorable characteristics most likely enabled the students to get well along with them, which seems to have contributed to students' English class with a good atmosphere. Therefore, the atmosphere in the class would be more relaxed, not stressful.

One external factor that could explain the results is parents' occupation. Kwong (1983) stated that parents' occupation influenced a child's 
educational opportunities because it determined the area of residences and thus the quality of the school. Office workers' children had more opportunities than the peasants' with better educational facilities in the cities, and the children of intellectuals out-perform all others with their additional support from home. In this study, the majority of students' parents' occupation was government officers and private sector officers, and it determined where they lived, which was urban area. This factor influenced the parents' thinking pattern, they felt necessary to send their children to additional English courses out of school. This could have given positive effect to the children and it would influence the learning of English in school. They had basic knowledge to bring to the classroom and this could make them less anxious.

A second external factor is the role of teacher. It is possible that English teachers at Sekolah Menegah Umum 1 Banjarbaru were able to create a lively climate in the classroom, therefore, able to make the learning context less stressful. Teachers could help students cope with anxietyproducing situations and made the learning context less stressful (Horwitz, Horwitz, \& Cope, 1986; Price, 1988; Horwitz \& Young, 1991; Aida, 1994; Cassado \& Dereshiwsky, 2001; Gregersen \& Horwitz, 2002; Daley, 2003; Wörde, 2003; Elkhafaifi, 2005; Meng \& Wang, 2006; Woodrow, 2006; Na, 2007). Teachers' characteristics or attitudes such as being helpful and encouraging could have played an important role in reducing students' anxiety in the Sekolah Menegah Umum 1 Banjarbaru classroom.

Another external factor that can influence language anxiety is students' residence area. Most students were from urban area. This factor was assumed to influence the students in communication; they could be more extrovert people, who are accustomed to communicate freely to everyone. If this is the case, this factor may influence their school life, including the English classroom.

\section{The correlation between anxiety and students' achievement in English as a foreign language}

Table 2 shows the correlation between anxiety dimensions and students' achievement. A weak negative correlation is seen between achievement and overall anxiety $(r=-0.120, p>$ 0.01 , not significant). A weak negative correlation is seen between achievement and communication apprehension $(\mathrm{r}=-0.094, \mathrm{p}>0.01$, not significant). And a weak negative correlation is also seen between achievement and fear of negative evaluation $(r=-0.032, p>0.01$, not significant). Although these two dimensions show the negative correlation to students' achievement, the possibility are higher than 0.01 , which means not significant or there is no correlation between communication apprehension and fear of negative evaluation to students' achievement. As a whole, between overall anxiety and students' achievement, the correlation is not significant at $\mathrm{p}<0.01$ level.

But between achievement and test anxiety, $\mathrm{r}=$ 0.210 , showing negative correlation between achievement and test anxiety, which is significant at $\mathrm{p}<0.05$ level. The negative sign shows that the higher the achievement, the lower the test anxiety and the lower achievement, the higher the test anxiety. This dimension has shown that foreign language anxiety is negatively associated with students' achievement.

Therefore, it can be concluded that there is no significant relationship between English language anxiety and students' achievement in English as a foreign language as a whole. Achievement also did not correlate significantly with communication apprehension and fear of negative evaluation.

Table 2

Result for Pearson correlations between anxiety dimensions and students' achievement

\begin{tabular}{|c|c|c|c|c|c|c|}
\hline & & 1 & 2 & 3 & 4 & 5 \\
\hline \multirow[t]{2}{*}{ 1. Achievement } & $\mathrm{r}$ & 1 & & & & \\
\hline & $\mathrm{p}$ & . & & & & \\
\hline \multirow[t]{2}{*}{ 2. Overall Anxiety } & $\mathrm{r}$ & -.120 & 1 & & & \\
\hline & $\mathrm{p}$ & .141 & . & & & \\
\hline \multirow[t]{2}{*}{$\begin{array}{l}\text { 3. Communication } \\
\text { Apprehension }\end{array}$} & $r$ & -.094 & $.953\left(^{* *}\right.$ & 1 & & \\
\hline & $\mathrm{p}$ & .248 & .000 & . & & \\
\hline \multirow[t]{2}{*}{$\begin{array}{l}\text { 4. Fear of Negative } \\
\text { Evaluation }\end{array}$} & $r$ & -.032 & $.898 C^{* *}$ & $.763 r^{* *}$ & 1 & \\
\hline & $\mathrm{p}$ & .697 & .000 & .000 & & \\
\hline \multirow[t]{2}{*}{ 5. Test Anxiety } & $\mathrm{r}$ & $.210{ }^{* * *}$ & $.937\left(^{* *}\right.$ & $.8311^{* *}$ & $.8133^{* *}$ & 1 \\
\hline & $\mathrm{p}$ & .009 & .000 & .000 & .000 & \\
\hline
\end{tabular}

In this study, the significant negative correlation between test anxiety and students' achievement supported the premise that anxiety will influence the achievement, which is, the higher the achievement, the lower the test anxiety and the lower achievement, the higher the test anxiety.

This study indicated high school students indeed had the feeling of anxiety in their English classrooms. And they experienced more anxiety in test situation. Rachman (2004) described test anxiety as people who experience intense anxiety when carrying out formal test or other tasks on which are they to be evaluated. 
One possible explanation for this result may lie in the students' English learning orientation. There are two orientations in learning English; integrative or instrumental orientations (Gardner \& MacIntyre, 1993). Most students in Indonesia, studying English as foreign language was for passing the examinations. It indicated that studying English has instrumental orientation. Compared with the students live in the countries where the English is as their second language, they study English for interaction out of the classroom.

Gardner \& MacIntyre (1993) demonstrated that reasons for studying a second language form a number difference factors in addition to the integrative and instrumental ones, depending upon the nature of the community and the language concerned. It is obvious that community in Indonesia, especially in Banjarbaru where the study was conducted, English is as foreign language and the purpose of learning English is for passing the examinations.

Connected with the result of this study, which is, anxiety influenced students' achievement, it is assumed that because students' orientation in learning English were passing the English examinations, they tended to feel anxious, when they had to face the examination, therefore their anxiety affected their achievement.

\section{The difference between the foreign language anxiety of male and female students}

Table 3

Rating scores, standard deviations and standard error Mean of students' anxiety by gender

\begin{tabular}{llcccc}
\hline \multicolumn{1}{c}{ Gender } & & N & Mean & $\begin{array}{c}\text { Std. } \\
\text { Deviation }\end{array}$ & $\begin{array}{c}\text { Std. } \\
\text { Error } \\
\text { Mean }\end{array}$ \\
\hline Overall anxiety & Male & 54 & 2.81 & .72 & .09 \\
& Female & 98 & 2.99 & .52 & .05 \\
\hline $\begin{array}{l}\text { Communication } \\
\text { apprehension }\end{array}$ & Male & 54 & 2.94 & .74 & .10 \\
& Female & 98 & 3.18 & .57 & .06 \\
\hline Fear of & Male & & & & \\
negative & & 54 & 2.68 & .73 & .09 \\
evaluation & & & & & \\
& Female & 98 & 2.76 & .53 & .05 \\
\hline Test anxiety & Male & 54 & 2.71 & .77 & .10 \\
& Female & 98 & 2.92 & .63 & .06 \\
\hline
\end{tabular}

Table 3 summarizes the group statistics of the anxiety dimensions by gender used in the research. The number of male respondents was 54; the number of female respondents was 98. The group statistics in the table indicates that all the values for dimensions measured in Likert Scale was around their midpoint with a standard deviation below 1 . Measured using 5 point Likert scale, for communication apprehension, male had $(\mu=2.94$, s.d $=0.74$ and s.e $\mu=0.10)$ and female had $(\mu=3.18$, s.d $=0.57$ and s.e $\mu=0.06)$, for fear of negative evaluation, male had $(\mu=2.68$, s.d $=$ 0.73 and s.e $\mu=0.09)$ and female had $(\mu=2.76$, s.d $=0.53$ and s.e $\mu=0.05$ ), for test anxiety, male had $(\mu=2.71$, s.d $=0.77$ and s.e $\mu=0.10)$ and female had $(\mu=2.92$, s.d $=0.63$ and s.e $\mu=0.06)$. And for overall anxiety male had $(\mu=2.81$, s.d $=$ 0.72 and s.e $\mu=0.09)$ and female had $(\mu=2.99$, s.d $=0.52$ and s.e $\mu=0.05$ ).

$\mathrm{t}$-Test for the sample was done in 2 steps. First step was testing whether variance from 2 populations can be assumed similar. And then doing test to know whether there was Mean Difference in population. Basically, t-Test requires the similarity of variance from 2 populations tested.

Table 4

Results of the t-Test for gender differences in foreign language anxiety

\begin{tabular}{|c|c|c|c|c|c|c|}
\hline & & $\mathrm{F}$ & Sig. & $\mathrm{T}$ & $\begin{array}{l}\text { Sig. 2- } \\
\text { tailed) }\end{array}$ & $\begin{array}{c}\text { Mean } \\
\text { Difference }\end{array}$ \\
\hline $\begin{array}{l}\text { Overall } \\
\text { Anxiety }\end{array}$ & $\begin{array}{l}\text { Equal } \\
\text { variances } \\
\text { assumed } \\
\text { Equal } \\
\text { variances } \\
\text { not } \\
\text { assumed }\end{array}$ & 9.61 & .002 & -1.69 & .09 & -.19 \\
\hline $\begin{array}{l}\text { Communicat } \\
\text { ion } \\
\text { Apprehension }\end{array}$ & $\begin{array}{l}\text { Equal } \\
\text { variances } \\
\text { assumed } \\
\text { Equal } \\
\text { variances } \\
\text { not } \\
\text { assumed } \\
\end{array}$ & 7.11 & .009 & -2.05 & .04 & -.24 \\
\hline $\begin{array}{l}\text { Fear of } \\
\text { Negative } \\
\text { Evaluation }\end{array}$ & $\begin{array}{l}\text { Equal } \\
\text { variances } \\
\text { assumed } \\
\text { Equal } \\
\text { variances } \\
\text { not } \\
\text { assumed }\end{array}$ & 6.56 & .011 & -.69 & .49 & -.08 \\
\hline Test Anxiety & $\begin{array}{l}\text { Equal } \\
\text { variances } \\
\text { assumed }\end{array}$ & 3.76 & .054 & -1.85 & .07 & -.21 \\
\hline
\end{tabular}

$\mathrm{t}$-Test results showed the difference English language anxiety between male and female occurred on communication apprehension; and it showed that female was more apprehensive than male in English communication. While on the other two dimensions; fear of negative evaluation and test anxiety, differences were not found in English language anxiety between male and female. There was also no difference in overall English language anxiety by gender at second (2nd) grade Sekolah Menengah Umum Negeri 1 Banjarbaru.

The result of this study concluded that the difference in English language anxiety between male and female occurred on communication apprehension; and it showed that female was 
more apprehensive than male in English communication. While on the other two dimensions; fear of negative evaluation and test anxiety, differences were not found differences in English language anxiety between male and female. For overall anxiety, there was no difference in English language anxiety by gender at second (2 $\left.{ }^{\text {nd }}\right)$ grade Sekolah Menengah Umum Negeri 1 Banjarbaru.

The researcher assumes that the reasons for the results can be explained in two factors; the difference in learning style and the difference in self confidence. Firstly, Francis \& Skelton (2005) stated that there has been work on gendered learning preferences which argues that girls tend to prefer collaborative group-work activities, reflection and discussion; while boys relish competition and prefer whole-class teaching than small group work. It shows the difference learning style between male and female. The difference in learning style may have caused female students in the school where the study was conducted to experience more apprehension in communication in English classroom than male students. Secondly, female students' were expected to have lower self confidence than male students, and were more anxious to express the ideas and to communicate in front of the class than male students. This statement is supported by McCarty (1986) wrote that women are more likely than men to express low self confidence in achievement situations. Self confidence refers to how individuals perceive their ability to succeed at a particular endeavor, or judge their effectiveness once a task is finished. In her study, McCarty found that women's levels of self confidence were never equal to those men. Women seemed to approach this achievement situation with significantly less confidence than peers who were men. This confidence gap did not disappear when men and women received identical cues about their performance. The result in this study supported McCarty's finding. Clark (1993) pointed out that women less self confidence in their ability to present their arguments persuasively as they approached the task and evaluated their performance less positively than did men after completing their message.

But as a whole, this study indicated that there was no differences foreign language anxiety between male and female, this results supported the conclusions reached by several investigators in earlier studies (Price, 1988; Aida, 1994; Woodrow, 2006; Na, 2007).

\section{Conclusion}

The results of this study indicated that the students' anxiety in learning English as foreign language at second $\left(2^{\text {nd }}\right)$ grade Sekolah Menengah Umum Negeri 1 Banjarbaru was at moderate level. This result is encouraging, and it is suggested that students' English level, which is above average for Indonesians, and age and good relationship with classmates, students' parents' occupation, the role of teacher and students' residence area generally helped to lower the anxiety levels.

There was no significant relationship between English language anxiety and students' achievement in English as a foreign language as a whole. Achievement also did not correlate significantly with communication apprehension and fear of negative evaluation. But a significant negative correlation between test anxiety and students' achievement was indicated. It was suggested that students' orientation in learning English was related to this findings. It is recommended that teachers inform and advise that studying English is not only for passing the examination but for life skill to the students. So, it is hoped that it can reduce the students' test anxiety and increase their motivation to study English for international communication.

The difference English language anxiety between male and female on communication apprehension is believed to be caused by the difference in students' learning style and the difference in students' self confidence. Teachers are encouraged to create the learning context that is less stressful, and to create the friendly and lively climate in the classroom for increasing the students' self confidence. And teacher are hoped to select the method and materials appropriately for the classroom according to students' learning style.

Last of all, creating a supportive and friendly classroom environment is quite important to reduce students' foreign language anxiety to increase students' achievement. However, the findings of this study could not be generalized to the overall students in Indonesia because the sample of this study was limited only at one school. 


\section{REFERENCES}

Aida, Y. 1994. Examination of Horwitz, Horwitz, and Cope's Construct of Foreign Language Anxiety: The case of Students of Japanese. Modern Language Journal, 78, 155-167.

Casado, M. A. \& Dereshiwsky, M. I. 2001. Foreign Language Anxiety of University Students. College Student Journal. Alabama: The Gale Group. Retrieved January 23, 2008 from http://www.encyclopedia.com/doc/1G1-84017191.html

Clark, R. A. 1993. Men's and Women's self confidence in persuasive, comforting, and justificatory communicative task. A journal of Research. Retrieved February 29, 2008 from http://findarticles.com/p/articles/mi_m2294/is_n9-10_v28/ai_14322493

Daley, C. E. 2003. Foreign language Anxiety and Student Attrition. Academic Exchange Quarterly. Rapid Intellect Group, Inc.

Retrieved January 31, 2008 from http://www.thefreelibrary.com/Foreign+language+anxiety+and+student+attritiona0107489426

Elkhafaifi, H. 2005. Listening Comprehension and Anxiety in the Arabic Language Classroom. The Modern Language Journal, 89, 206-220.

Francis, B. \& Skelton, C. 2005. Reassessing Genderand Achievement: Questioning contemporary key debates. USA: Routledge.

Gardner, R. C. \& MacIntyre, P. D. 1993. On the Measurement of Affective Variables in Second Language Learning. Language Learning, 43, 157-194.

Gregersen, T. \& Horwitz, E. K. 2002. Language Learning and Perfectionism: Anxious and NonAnxious Language Learners' Reactions to Their Own Oral Performance. The Modern Language Journal, 86, 562-570.

Horwitz, E. K. 1986. Preliminary Evidence for the Reliability and Validity of a Foreign Language Anxiety Scale. TESOL Quarterly, 20, 3, 559-562.

Horwitz, E. K. 2001. Language Anxiety and Achievement. Annual Review of Applied Linguistics, 21, 112-126. USA: Cambridge University Press.

Horwitz, E. K., Horwitz, M. B., \& Cope, J. 1986. Foreign Language Classroom Anxiety. The Modern Language Journal, 70, 125-132.

Horwitz, E. K., \& Young, D. J. 1991. Language Anxiety: From Theory and Research to Classroom Implications. New Jersey: Prentice-Hall, Inc.

Kwong, J. 1983. Is everyone equal before the system of grades: social background and opportunities in China. The British Journal of Sociology, 34, 93-108.

McCarty, P. A. 1986. Effects of feedback on the self confidence of men and women. Academy of Management Journal, 28, 840-847.

Meng, X. \& Wang, Q. 2006. Psycological Factors and Teachers' Language. US-China Foreign Language, 4,5 .

Na, Z. 2007. A Study of High School Students' English Learning Anxiety. Asian EFL Journal, 9, Issue 3, Article 2, Retrieved January 29, 2008 from http://www.asian-efljournal.com/Sept_2007_zn.php 
Price, M. L. 1988. Anxiety and the Foreign Language Learner: Correlates of Foreign Language Anxiety. Unpublished doctoral dissertation. University of Texas, Austin.

Rachman, S. 2004. Anxiety (2nd Ed.). NY: Psychology Press Ltd.

Wachidah. (2004, June 27). English, Please!. Republika Online. Retrieved February 26, 2008 from http://202.155.15.208/koran_detail.asp?id=165008\&kat_id=253\&kat_id1=\&kat_id2=

Woodrow, L. 2006. Anxiety and Speaking English as a Second Language. RELC Journal, 37, 308328. Retrieved February 1, 2008 from http://rel.sagepub.com/cgi/reprint/37/3/308

Wörde, R. V. 2003. Students' Perspectives on Foreign Language Anxiety. Inquiry, 8, 1. Retrieved January 16, 2008 from http://www.vccaedu.org/inquiry/inquiry-spring2003/i-81worde.html 